\title{
Testicular Mixed Embryonal Carcinoma and Seminoma
}

National Cancer Institute

\section{Source}

National Cancer Institute. Testicular Mixed Embryonal Carcinoma and Seminoma. NCI

Thesaurus. Code C6350.

A malignant mixed germ cell tumor arising from the testis. It is characterized by the presence of a mixture of embryonal carcinoma and a seminomatous component. 